\title{
Uterine Corpus Adenosarcoma pT2a TNM
} Finding v8

National Cancer Institute

\section{Source}

National Cancer Institute. Uterine Corpus Adenosarcoma pT2a TNM Finding v8. NCI

Thesaurus. Code C139858.

Uterine corpus adenosarcoma with tumor extending beyond the uterus, within the pelvis and involving adnexa. (from AJCC 8th Ed.) 